\title{
Variants of Papillary Thyroid Carcinoma: Multiple Faces of a Familiar Tumor
}

\author{
Serpil DIZBAY SAK \\ Department of Pathology, Ankara University, Faculty of Medicine, ANKARA, TURKEY
}

\begin{abstract}
Classically characterized by its papillary appearance, papillary thyroid carcinoma is the most common malignant neoplasm of the thyroid. Several variants of papillary carcinoma have been described considering size (microcarcinoma); nature of the tumor boundaries (encapsulated); architecture (follicular, macrofollicular, cribriform-morular, solid, micropapillary); cellular characteristics (tall cell, columnar, oncocytic, clear cell, hobnail); additional tumor components (papillary carcinoma with focal insular component, papillary carcinoma with spindle and giant cell carcinoma, papillary carcinoma with squamous cell carcinoma, papillary carcinoma with mucoepidermoid carcinoma); stromal features (papillary carcinoma with fasciitis like stroma); or a combination of the abovementioned characteristics (diffuse sclerosing, Warthin-like). Although most variants do not pose any diagnostic problems; some histological variants can be challenging to the pathologist and some are of clinical significance, because of prognostic implications or accompanying clinical conditions. It is not rare to find a papillary carcinoma showing characteristics of more than one variant. For example: an individual tumor can show hobnail features and present as a microcarcinoma; another case can show solid architecture and clear cytoplasm. In such cases, it is more important to comment on clinically relevant morphological characteristics of the tumor, rather than religiously trying to classify an individual tumor into a particular variant. In this review, pathologic and clinical features of papillary carcinoma variants are summarized.
\end{abstract}

Key Words: Papillary thyroid carcinoma, Thyroid cancer, Genetics, BRAF, RAS

\section{INTRODUCTION}

The most common malignant tumor of the thyroid is papillary carcinoma (1). Classically characterized by its papillary appearance, papillary thyroid carcinoma (PTC) accounts for approximately $80 \%$ of all thyroid carcinomas. Several variants of papillary carcinoma have been described considering size (papillary microcarcinoma); nature of the tumor boundaries (encapsulated); architecture (follicular, macrofollicular, cribriform-morular, solid, micropapillary); cellular characteristics (tall cell, columnar, oncocytic, clear cell, hobnail); additional tumor components (papillary carcinoma with focal insular component, papillary carcinoma with spindle and giant cell carcinoma, papillary carcinoma with squamous cell carcinoma, papillary carcinoma with mucoepidermoid carcinoma); stromal features (papillary carcinoma with fasciitis like stroma); or a combination of the abovementioned characteristics (diffuse sclerosing, diffuse follicular) (1-4). Although most variants do not pose any diagnostic problems; some histological variants can be challenging to the pathologist and some are of clinical significance, because of prognostic implications or accompanying clinical conditions (1-4). In this review, the pathologic and clinical features of papillary carcinoma variants will be summarized.

(Turk Patoloji Derg 2015, 31(Suppl):34-47)

Received : 15.06.2015 Accepted : 16.06.2015

\section{PAPILLARY MICROCARCINOMA}

Although the term 'papillary microcarcinoma' does not refer to any morphologic characteristics, in some schemes papillary carcinomas smaller than $1 \mathrm{~cm}$ are considered as a variant (Figure 1A,B) (1). The terms 'occult', 'latent' and 'small' papillary carcinoma have been used as a synonym for these tumors. It is a very common incidental finding in autopsy studies (6-36\%) and in thyroids removed for other reasons (5-24\%). More papillary microcarcinomas are being identified and biopsied in recent years, probably due to the increased use of ultrasound; making it the most common variant of papillary carcinoma in some countries (1-3,5-7).

It shows a tendency to be located near the capsule and is often none encapsulated. Microcarcinomas do not have a distinctive morphology; all growth patterns and cellular features that can be observed in larger papillary carcinomas can be observed in papillary microcarcinomas (1-3,5-7). RET rearrangements are a frequent finding in papillary microcarcinoma and in a recent meta-analysis the prevalence of $B R A F^{V 600 E}$ mutation was reported as $47.48 \%$ $(7,8)$.

Correspondence: Serpil DİZBAY SAK

Ankara Üniversitesi Tip Fakültesi, Patoloji Anabilim Dalı

ANKARA, TURKEY

E-mail: sak@medicine.ankara.edu.tr Phone: +90 3125958295 
Most papillary microcarcinomas represent a clinically indolent disease. A meta-analysis has shown that $28 \%$ had metastatic lymph node(s), $0.7 \%$ had metastatic disease and only $0.3 \%$ died of the disease (3). Factors found to be associated with high risk disease include male gender, tumor size $>5 \mathrm{~mm}$, bilateral/multifocal location, lower third of the thyroid lobe location, lymph node metastasis at presentation, superficial tumor location, capsule invasion/ extrathyroidal extension, BRAF mutation and stromal fibrosis $(3,7)$. The term 'papillary microtumor' has been proposed because of the high incidence and benign clinical behavior of this group of neoplasms. This terminology excludes tumors in patients less than 19 years of age and tumors with metastases, which may have a different biology (9).

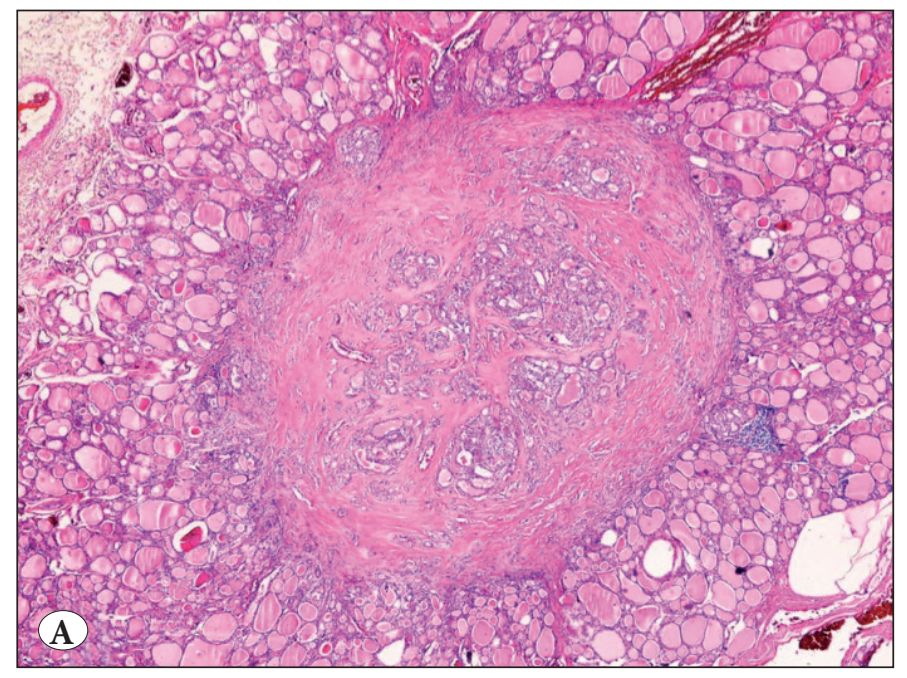

\section{FOLLICULAR VARIANT}

This is a common variant of PTC with an increasing frequency, comprising about 20-30 \% of all papillary carcinomas. It is composed exclusively or almost exclusively of follicles lined by cells showing nuclear features of papillary carcinoma; well-formed papillae should not be observed in follicular variant of papillary carcinoma (FV-PTC) (1-4).

This variant commonly presents as a well circumscribed or encapsulated tumor (Figure 2A) and as a result of encapsulation and follicular architecture, it may be mistaken for follicular adenoma or follicular carcinoma. Although FV-PTC is distinguished from follicular adenoma and carcinoma by its characteristic 'papillary' nucleus; nuclear features are often more subtle than that

Figure 1: A) Microcarcinoma with a desmoplastic stroma, B) This incidental microcarcinoma consists of a single follicle.
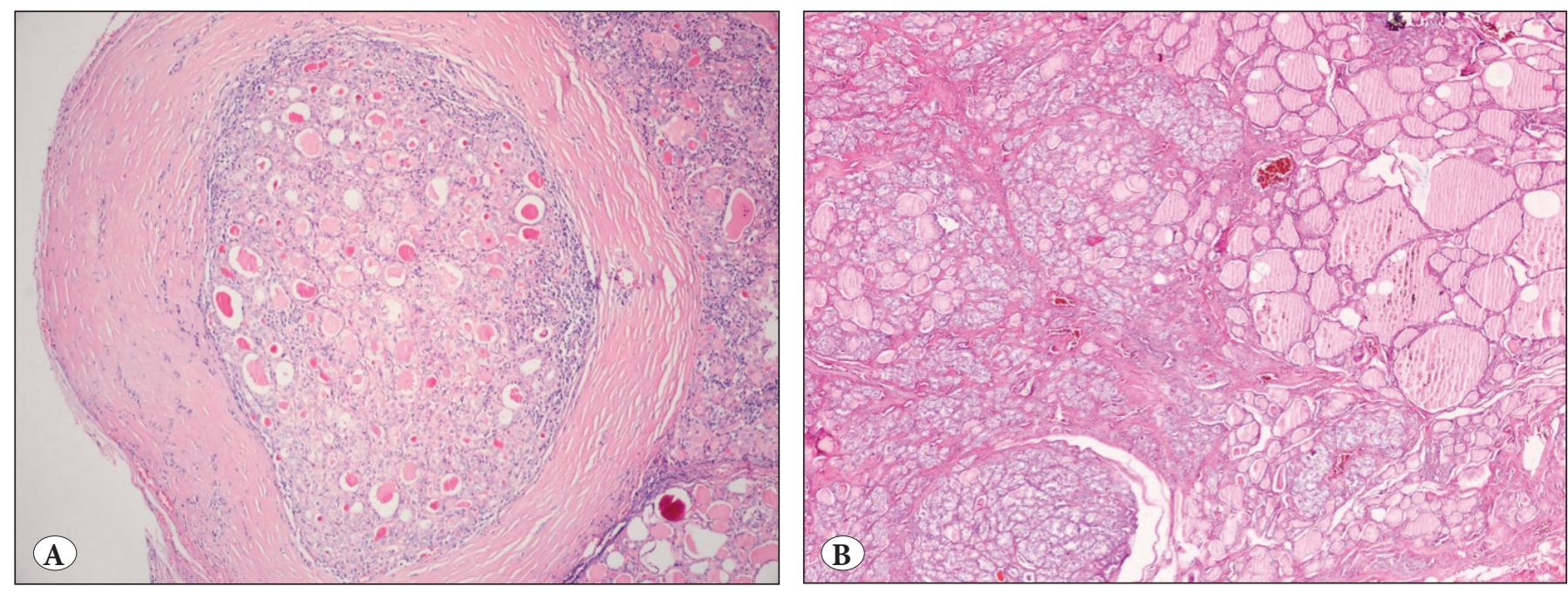

Figure 2: A) An encapsulated small tumor, consisting of follicles: (Encapsulated) follicular variant of papillary (micro) carcinoma. B) A follicular variant PTC with infiltrative character. 
of conventional PTC, making this variant one of the most controversial entities of surgical pathology, largely due to the lack of consensus on when to (or not to) diagnose the nuclear features of papillary carcinoma $(3,4,10-14)$. When FV-PTC is unencapsulated and infiltrates the surrounding thyroid parenchyma, the diagnosis of carcinoma usually is not a problem (Figure 2B, 3A,B). On the other hand, the diagnosis of noninvasive, encapsulated FV-PTC versus FA is subject to considerable interobserver variability. The lack of consensus is demonstrated by several studies reporting a great interobserver variability in diagnosing encapsulated FV-PTC, even among expert thyroid pathologists $(15,16)$. Abundant nuclear grooves, intranuclear inclusions and psammoma bodies which are very helpful in diagnosis, are less common in FV-PTC. Additional reasons for difficulty in diagnosing these lesions include the lack of capsular and/or vascular invasion in majority of cases and multifocal rather than diffuse distribution of 'papillary' nuclear features $(3,4,10-16)$. When therapeutic consequences are taken into account, it is practical to consider the entire nodule containing multiple foci diagnostic of PTC, as a single malignant nodule (13). Follicular variant PTCs often have irregularly shaped follicles which sometimes contain thick, hypereosinophilic colloid with a scalloped appearance at the periphery of the follicles, similar to that seen in Graves' disease; multinucleated giant cells of macrophage derivation may be observed within follicles $(3,4,14)$.

In cases where the nuclear features are suggestive, but not diagnostic of FV-PTC, immunohistochemical staining for HBME-1, galectin-3, CITED1 and CK19 may be useful to support the diagnosis of malignancy (Figure 4A,B) $(3,4,17$ 21). HBME-1 positivity with an apical and/or membranous
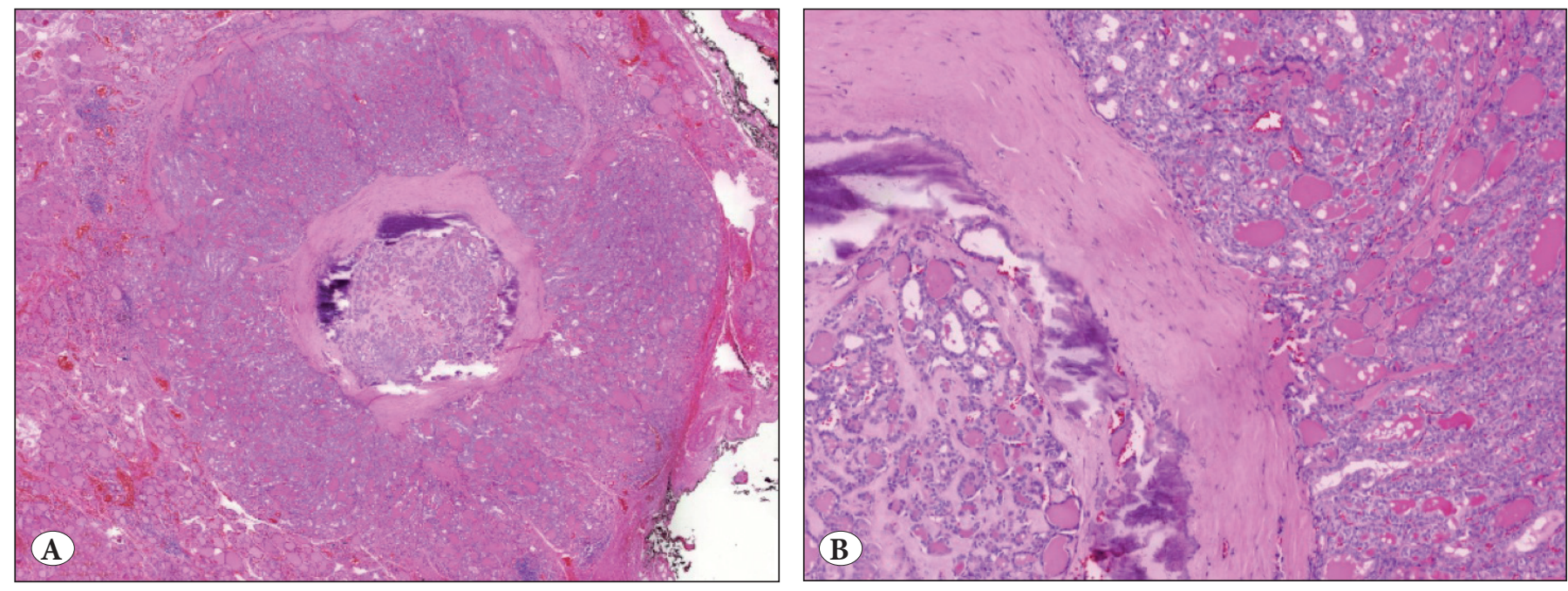

Figure 3: A) Follicular variant of PTC; there is an encapsulated component in the center. B) Higher magnification of the same tumor.
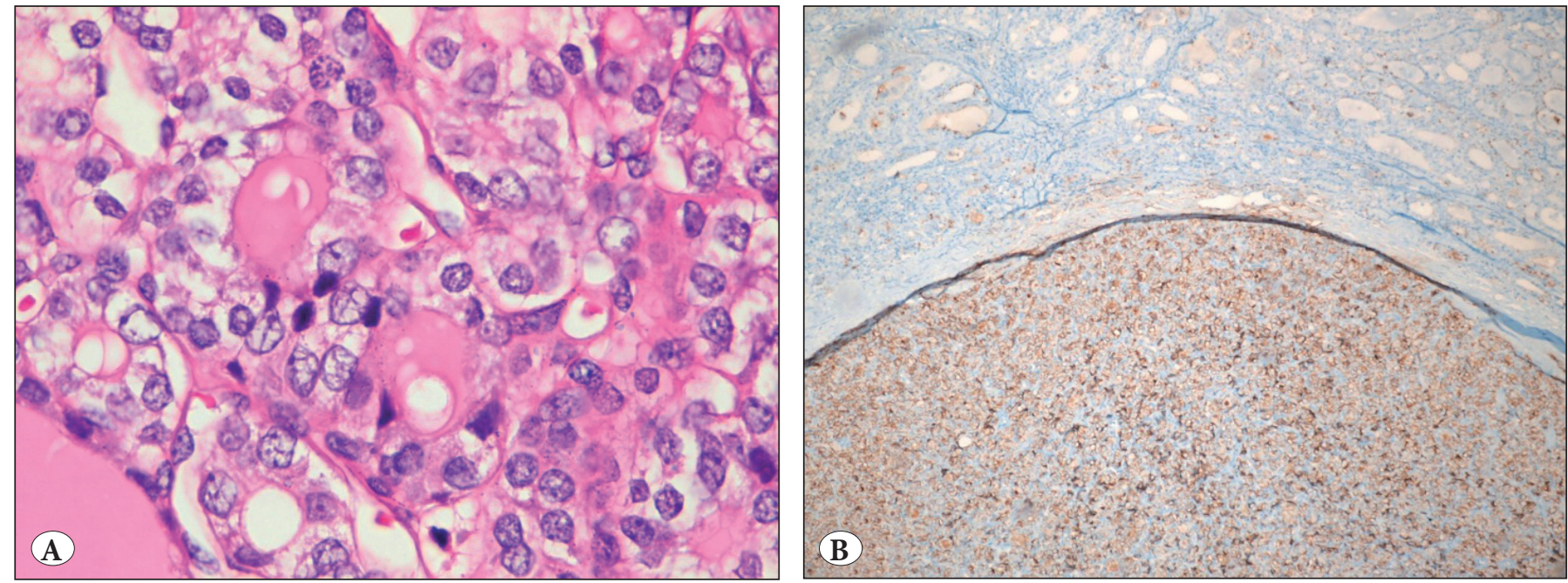

Figure 4: A) Follicular variant of PTC; nuclear features are suggestive of papillary carcinoma B) HBME1 positivity confirms PTC diagnosis. 
pattern is suggestive of malignancy, but lack of staining does not exclude FV-PTC. Diffuse and membranous CK19 staining is helpful, but not specific, as it can be seen in benign lesions $(3,4,14)$. It has been shown that membranous HBME-1, membranous CK19, and/or nuclear galectin-3 staining predicts an increased risk of lymph node metastasis in follicular lesions (22). However, the diagnosis of PTC should not rely solely on immunohistochemistry and suggested immunohistochemical markers should be tested for their performance in each individual laboratory, before using them as a diagnostic tool.

From a molecular pathologic point of view, this variant shows some genetic differences from classic papillary carcinoma (BRAF K601E mutation, higher frequency of RAS mutations, PAX8/PAR $\gamma$ rearrangement) and shares some of the molecular features of follicular carcinoma $(3,4,13,14)$. This is particularly true for the encapsulated/ well-circumscribed FV-PTC (23).

Previously, it was believed that tumors with the characteristic nuclear features of papillary carcinoma would behave clinically as conventional papillary carcinoma; however, as more knowledge accumulated, it became clear that FV-PTC is not a homogeneous group $(13,14,24-26)$. The infiltrating (unencapsulated) subgroup has a metastatic potential for nodal metastases and these tumors behave as usual papillary carcinoma with similar metastatic patterns and rare extracervical metastases. The other subtype which is referred to as encapsulated follicular variant (EFV-PTC) is characterized by total encapsulation and behaves more like follicular adenoma or follicular thyroid carcinoma, depending on the presence or absence of capsular/vascular invasion. In the absence of invasion, the behavior of these tumors are almost always indolent, even after lobectomy (13,14,24-26). However, extremely rare cases of metastasizing noninvasive EFV-PTC are encountered in the literature (27).

Considering the difficulties and inconsistencies in diagnosis, designating lesions with incomplete or equivocal features (i.e., minor nuclear changes or questionable/minimal capsular invasion) of FV-PTC as "well differentiated thyroid tumor of uncertain malignant potential" has been suggested; however this approach is not widely accepted $(3,13,28)$. More recently, the idea of deleting the term carcinoma from the nomenclature of noninvasive EFVPTC, which is extremely low malignant potential, is gaining some acceptance, in view of the adverse effects of over treatment (24).

\section{MACROFOLLICULAR VARIANT}

This variant usually presents as a nodule which is predominantly ( $>50 \%$ of a cross-sectional area) composed of large $(>200-250 \mu \mathrm{m})$ follicles $(1,3,4)$. Because of the macrofollicular pattern, the differential diagnosis with benign diseases such as goiter or macrofollicular adenoma may be challenging (Figure 5) $(1,3,4,29)$. In addition, not all of the cells lining the macrofollicles are typical of papillary carcinoma. Finding the follicles lined by cells with large vesicular nuclei with characteristic grooves and inclusions are diagnostic. The macrofollicles are maintained in the lymph node metastases (1). Based on a meta-analysis of 51 cases, the incidence of lymph node and distant metastases are $20 \%$ and $6 \%$ respectively (3). A rare case with anaplastic transformation and two cases with disseminated lung metastases have been reported (30).

\section{DIFFUSE (MULTINODULAR) FOLLICULAR VARIANT}

This rare variant is characterized by multifocal involvement of one or both thyroid lobes and typically occurs in young females (1,3). Multiple nodules some of which extend beyond the thyroid capsule are seen on gross examination. On microscopy, nodules with follicular organization are observed; nodules may show encapsulation or invasive growth (Figure 6). This is an aggressive variant showing frequent vascular invasion and extrathyroidal extension; lymph node and distant metastases are common $(1,3,31)$.

\section{SOLID VARIANT}

Solid variant of papillary thyroid carcinoma (SV-PTC), which is dominated by solid sheets of tumor cells, represents approximately $3 \%$ of all papillary carcinomas and it is more common among children, particularly among

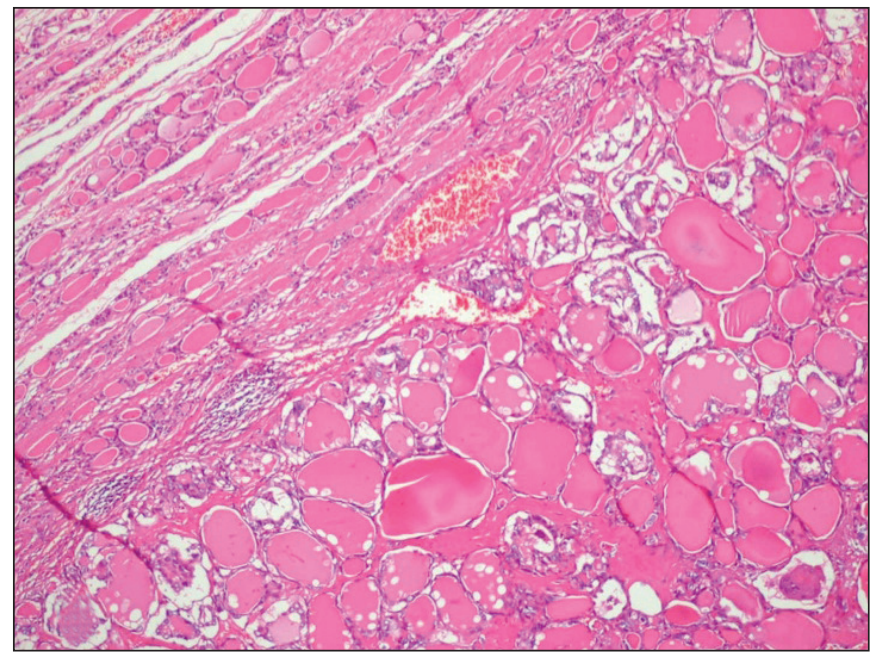

Figure 5: Large follicles surrounded with typical papillary carcinoma cells: macrofollicular variant. 


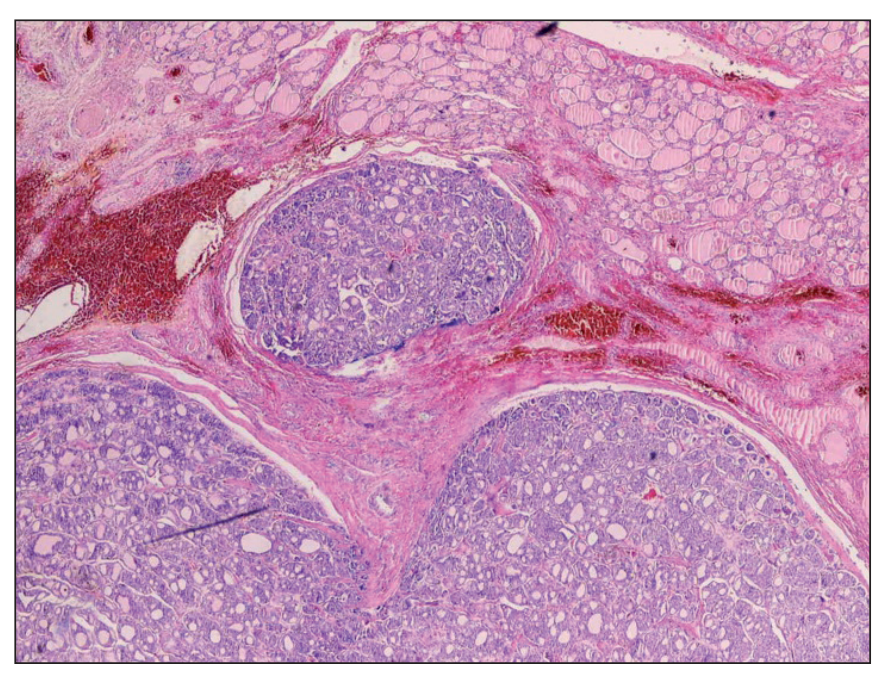

Figure 6: Multiple malignant follicular nodules: multinodular follicular variant.

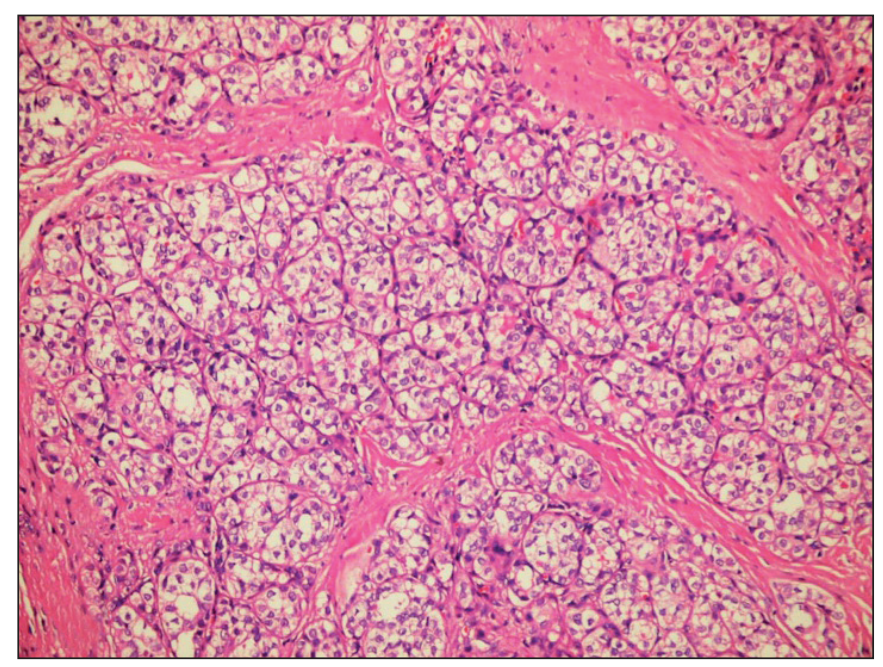

Figure 7: Solid variant of PTC. This tumor has clear cytoplasm, which will also qualify for clear cell carcinoma.

those exposed to ionizing radiation (1-5). This variant is characterized by invasive borders and is dominated by solid sheets and nests of tumor cells with typical nuclear features of papillary carcinoma (Figure 7). There may be vague papillary formations and/or a partial follicular pattern. This variant may be evaluated within the spectrum of follicular variant, in which the proliferating activity of the tumor cells is predominating over the secretory activity (2). The differential diagnosis of this variant from poorly differentiated (insular) carcinoma may be difficult because of the architectural resemblance. Well-developed nuclear features of papillary carcinoma that are usually present in SV-PTC, should be sufficient for a PTC diagnosis, irrespective of architecture. However, marked nuclear pleomorphism, mitotic activity, and necrosis should prompt the suspicion of poorly differentiated carcinoma (1). In pediatric SV-PTC, developed after the Chernobyl nuclear accident, RET/PTC rearrangement is found to be very frequent (32). Activating classical BRAF mutations are not found in SV-PTC (3). Solid variant is associated with more aggressive behavior and a higher frequency of distant metastasis in adults (3).

\section{CRIBRIFORM-MORULA(R) VARIANT (CRIBRIFORM CARCINOMA)}

This is a tumor considered as a variant of papillary carcinoma by some, and a distinct entity in by others (1). It was first reported in 1994 and was noted to be associated with familial adenomatous polyposis (FAP) syndrome (33). CMV-PTC is a rare tumor and constitutes less than $0.5 \%$ of PTC. Patients are usually young women, mean age being 25-27 years. It typically occurs in association with FAP or Gardner syndrome. In this setting, tumor is usually multifocal; however, a solitary counterpart occurs in patients who do not carry a germline adenomatous polyposis coli (APC) gene mutation (1-4,33).

It is characterized by cribriform, solid, trabecular, squamoid (morular) patterns mixed with papillary and follicular areas (Figure 8A,B) (1-4,33). Morules, typical features of this variant, may be difficult to find or nonexistent in some cases. The tumor cell nuclei are often hyperchromatic and pseudostratified, although typical nuclei are also found. Some nuclei within the morules contain a lightly eosinophilic homogeneous appearance, caused by biotin accumulation. Colloid is scanty or absent. Recently, an interesting finding characterized with hyaline globules as seen in adenoid cystic carcinoma of the salivary glands was described in a case of cribriform morular variant of PTC (34). CMV-PTC may be a challenge for the pathologist because of its unfamiliar morphology and also focal thyroglobulin positivity (3). Fortunately, TTF1 expression is well preserved. These tumors have RET/ PTC rearrangements, that are characteristic of papillary carcinoma; BRAF mutations are not present (3).

Behavior of CMV-PTC is similar to that of conventional PTC (1-4,33). Recognizing CMV-PTC should prompt colonic examination (3).

\section{MICROPAPILLARY (HOBNAIL) VARIANT}

Micropapillary variant (MPV) of PTC is rare, with a prevalence of $<2 \%$ and a mean age of 65 years (35). Histologically, this variant is characterized by micropapillae lacking true fibrovascular cores; cells have an eosinophilic cytoplasm and apically placed nucleus with a decreased nucleus/cytoplasm ratio resulting a "hobnail" appearance 
(35-40). There is usually an abrupt transition between the micropapillary component and conventional PTC areas, and micropapillae usually occur at the invasive edge of the tumor. According to a study of 10 cases, MPV-PTC shows either BRAF V600E (\%80) mutation or RET/PTC1 (\%20) rearrangement (39). P53 immunostaining is also described suggesting a mutation in this variant (37). MPV-PTC appears to behave more aggressively than classical papillary thyroid carcinoma (35-40). It is a predictor of lymph node metastases and cancer-related death is more frequent than the classical type, even when micropapillary component is as little as $10 \%$ of the tumor (37). Mortality is reported to be higher than that of conventional PTC, reported as 57\%, after 8.5 years of follow-up.

\section{TALL CELL VARIANT}

This variant is characterized by predominance of "tall" cells. The WHO blue book describes it as a papillary carcinoma composed predominantly of cells whose heights are at least three times their widths (1). However, in the original definition by Hawk and Hazard it was described as characterized by a population of neoplastic cells having a height that is at least two times the width in an otherwise typical papillary carcinoma and in some studies a height to width ratio $>2$ is accepted as sufficient (41-43). There is also no standard definition available concerning the proportion of tall cells required. Probably as a result of this nonstandard approach, its incidence varies between $3.2-19 \%$ of papillary thyroid cancers $(3,42,44)$. In a recent study, the prevalence of tall cell variant of papillary thyroid carcinoma (TCV-PTC) was found to be more frequent in Graves' disease (18\% in Graves' disease, versus 6.1\% in nonGraves' patients) (45). In most studies, this variant presents at an older age group and it is rare among pediatric and young patients $(1,3)$.

Tall cells have basally oriented nuclei showing classical nuclear features of papillary carcinoma and abundant eosinophilic cytoplasm, which is probably due to increased mitochondria. This variant shows numerous papillae; close packing of papillae and thin elongated follicles gives the impression of trabeculation (Figure 9A,B) (1-4). Tumors containing a minor $(>\% 50)$ tall cell component should not be included into TCV-PTC, however it is recommended to note the presence of tall cell features in the report, because of possible negative effect on prognosis. BRAF mutation is very common in this variant (3).

Tall cell variant is considered as more aggressive than conventional papillary carcinoma with larger tumors, more frequent extrathyroidal extension, higher recurrence and mortality rate $(1-4,46,47)$. Recently two TCV-PTC cases clinically presenting with brain metastasis are described (48).

The poorer prognosis may be partially related to the higher stage at presentation and older patient age; however some studies have shown that this variant has a lower disease free survival when compared to age and stage matched classic papillary carcinoma (47).

\section{COLUMNAR CELL VARIANT}

This is a rare tumor (about $0.2 \%$ of PTC) which shows pseudostratification of elongated cells which may contain subnuclear or supranuclear cytoplasmic vacuoles reminiscent of those of early secretory endometrium (1-4). Mixed tall/ columnar cell carcinomas can be observed and some authors accept this tumor as an extreme form of tall cell variant. CCV-PTC tends to occur in older individuals (49-53).
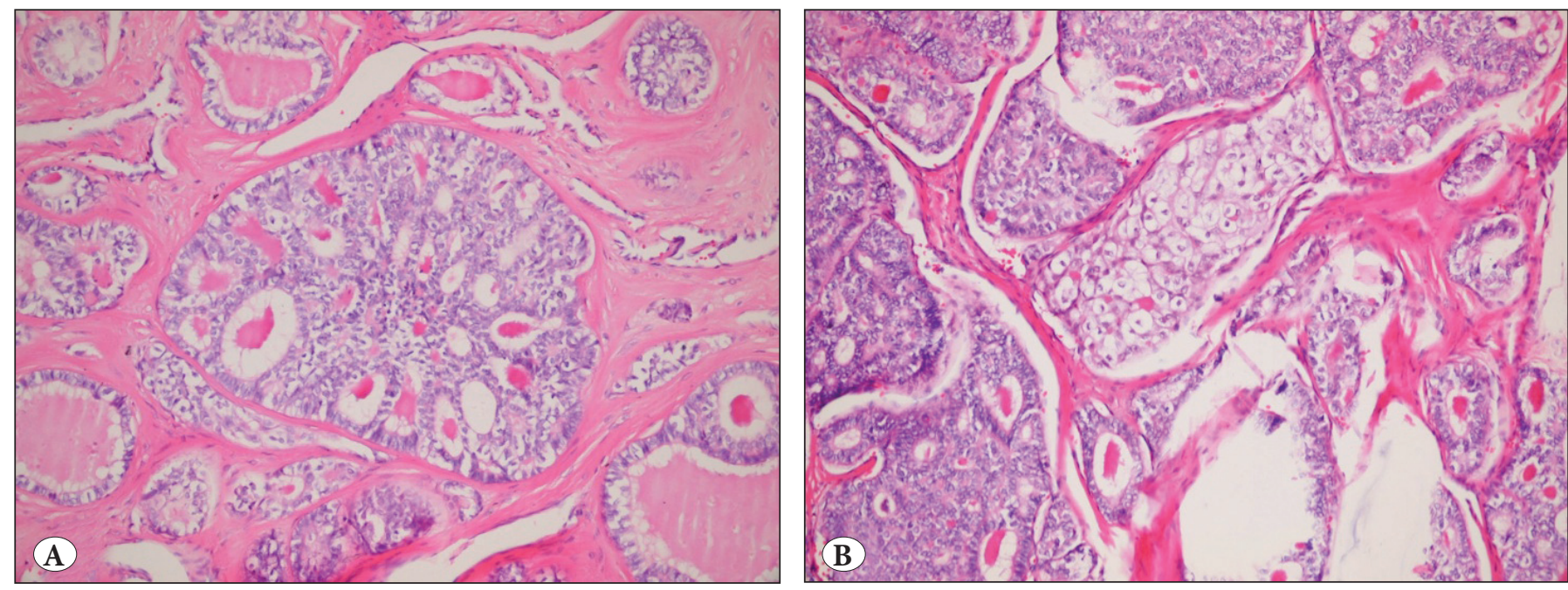

Figure 8: A,B) Cribriform morular variant of papillary carcinoma showing cribriform arrangement and B) A morule in the center. 
Papillary, follicular and trabecular and solid growth patterns can be seen. The classic nuclear features (clearing, grooves, and inclusions) of conventional PTC are not frequent (Figure 10A,B). Overall morphology may resemble adenocarcinoma of the endometrium or intestinal tract (14). In addition, an interesting finding, characterized with hyaline globules as seen in adenoid cystic carcinoma of the salivary glands, was described in two cases of CCV-PTC (34). Thyroid origin of this variant needs to be confirmed; especially in metastatic sites especially with TTF1, because thyroglobulin staining may be patchy and weak (56). It may be useful to note that CDX2 reactivity alone should not be used to confirm intestinal origin, because CDX2 expression was identified in $10-55 \%$ of CCV-PTC $(54,55)$. Along the same line, estrogen receptor (ER) expression should not be interpreted as a proof of endometrial origin, as ER is found to be positive in two thirds of CCV-PTC cases (56). BRAF mutation (V600E) is identified in one third of this variant (56).

These tumors show a more aggressive clinical behavior than conventional papillary carcinomas $(10,11,22,26,56)$; however, behavior seems to be associated, at least partially, with tumor burden rather than the histological type per se (53). Hence, it was suggested that CCV-PTC can be separated into circumscribed and widely invasive subtypes, corresponding to indolent and aggressive clinical behavior respectively.
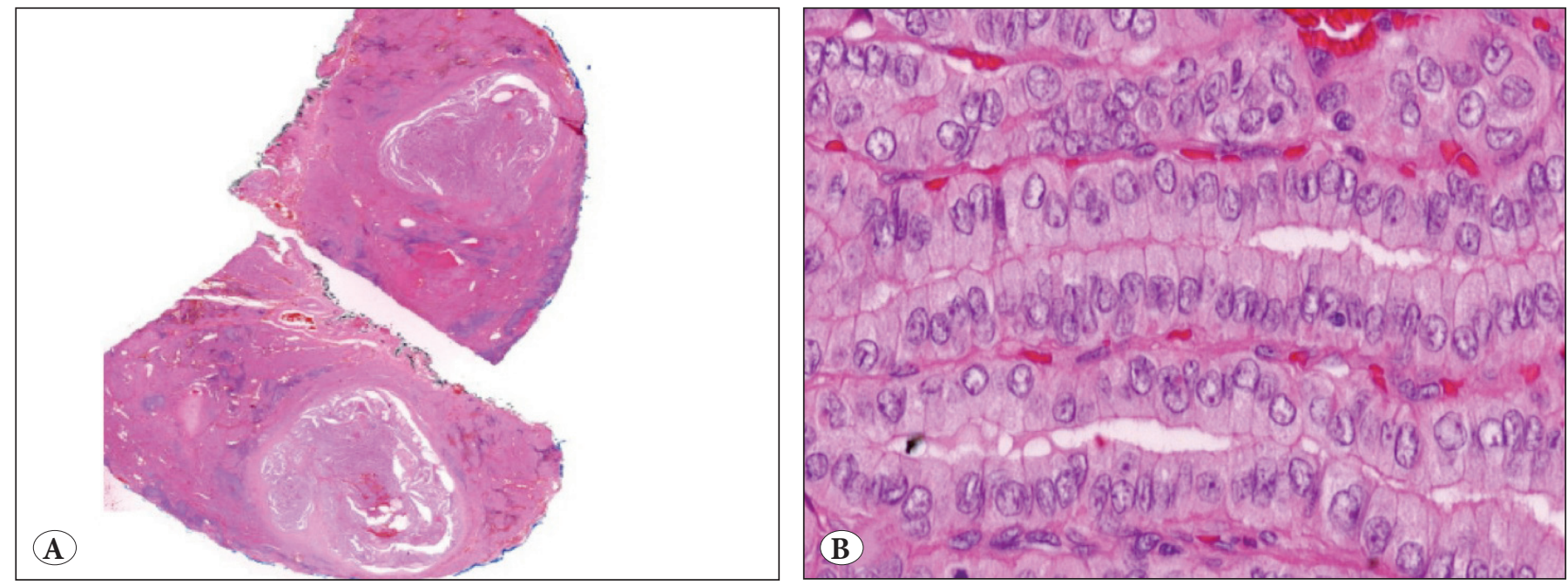

Figure 9: A) A small and well circumscribed tumor with tall cells: tall cell variant. B) Higher magnification: trabecula like arrangement of closely packed papillae.
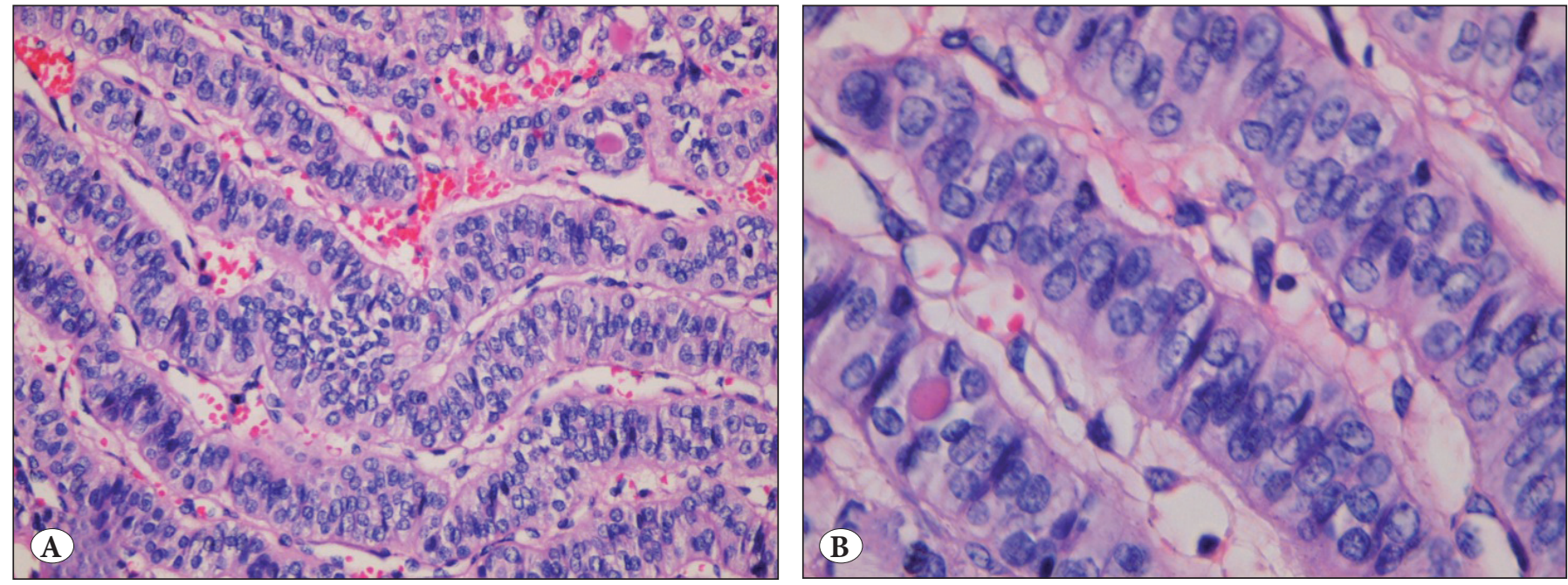

Figure 10: A) Columnar cells forming trabecula : columnar variant. B) The nuclear features are different than that of conventional PTC. 


\section{ONCOCYTIC (OXYPHIL, HURTHLE CELL) VARIANT}

This variant accounts for 1-11\% of all papillary carcinomas (57). Oncocytic features may be seen in both malignant and benign tumors and in non neoplastic conditions in thyroid. Oncocytic appearance is due to an increased number of mitochondria within the cytoplasm associated with a deficient mitochondrial function leading to proliferation of these organelles. This variant is a papillary carcinoma with classical nuclear characteristics, showing an oncocytic cytoplasm (1-4). The cytoplasmic characteristic reflects itself with the typical mahogany brown color of Hurthle cell neoplasms on gross examination. It may present as an encapsulated tumor (Figure 11A). Papillary architecture alone should not be equated with a malignant diagnosis and attention to the distinctive nuclear features is of importance to separate this entity from other thyroid tumors with oncocytic cytoplasm (Figure 11B) (58). It may show papillary or follicular architecture or may be solid. It may be mistaken for (oncocytic) follicular adenoma or carcinoma if the nuclear characteristics are overlooked. Chronic lymphocytic thyroiditis is found in the background of approximately half of the cases and implicated in pathogenesis. Both BRAF and $R E T / P T C$ rearrangements are frequent in these tumors $(60,61)$. In addition, mitochondrial DNA mutations which are related with the oncocytic morphology are common $(3,4,59)$. It is generally thought that this variant does not have any prognostic implications (1), although there are some reports suggesting a more aggressive behavior. This suggestion is most probably due to inclusion of tall cell variant in the group of oncocytic variant PTC.

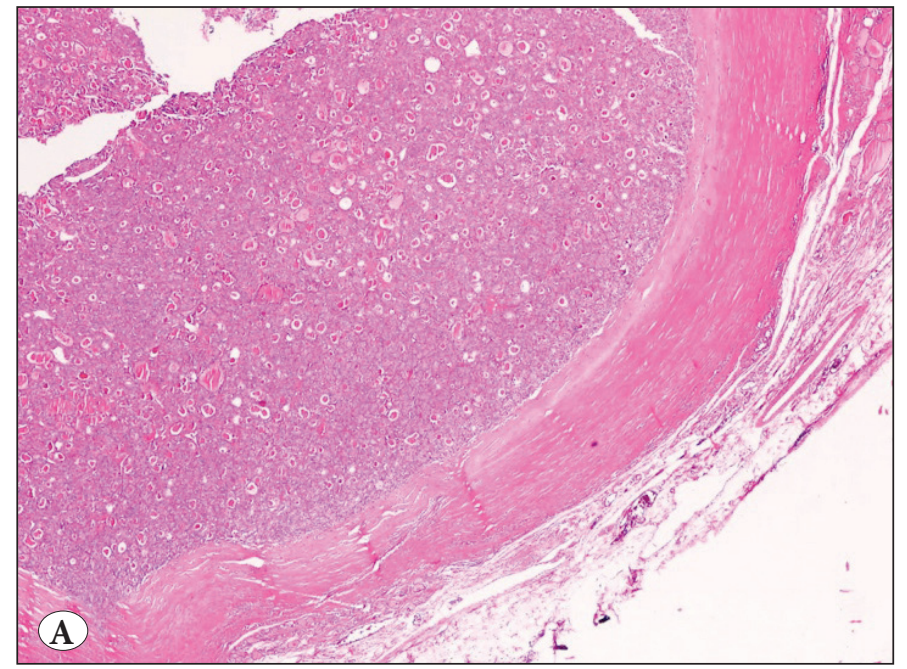

\section{WARTHIN LIKE VARIANT}

Warthin like variant papillary carcinomas (WLV-PTC) are characterized by papillae covered by oncocytic cells with fibrovascular cores infiltrated with lymphoid cells, reminiscent of Warthin tumor of the salivary gland (Figure $12 \mathrm{~A}, \mathrm{~B})(1,-4,62,63)$. WLV-PTC shows a strong female predominance and has a wide age range; mean age in different series range from 39 to $64(62,63)$. It is frequently associated with thyroiditis in the rest of the gland. Except for the prominent stromal lymphoid infiltration, the cytologic features of Warthin-like tumor may be reminiscent of tall cell and columnar cell variants of papillary carcinoma, that tend to show more aggressive clinical outcome. There is no prognostic significance attributed to this variant of papillary carcinoma except for one reported case with an area of dedifferentiation and one other case leading to death, with progression to anaplastic carcinoma (62-65).

\section{CLEAR CELL VARIANT}

This variant is rare and composed predominantly of cells with a clear cytoplasm and typical papillary nuclei (1-4). It may be related with oncocytic variant in some cases and it is characterized by a predominance of clear cells with an admixture of oncocytic cells (3). In some cases, clear cells may be PAS positive and diastase sensitive, consistent with cytoplasmic glycogen deposition (3). Architecture is predominantly papillary although some tumors may have a follicular or insular organization $(1,3)$. Separation from metastatic renal cell carcinoma, parathyroid tumors, clear cell medullary carcinoma and other clear cell tumors can be made by the presence of typical PTC nuclei, but may

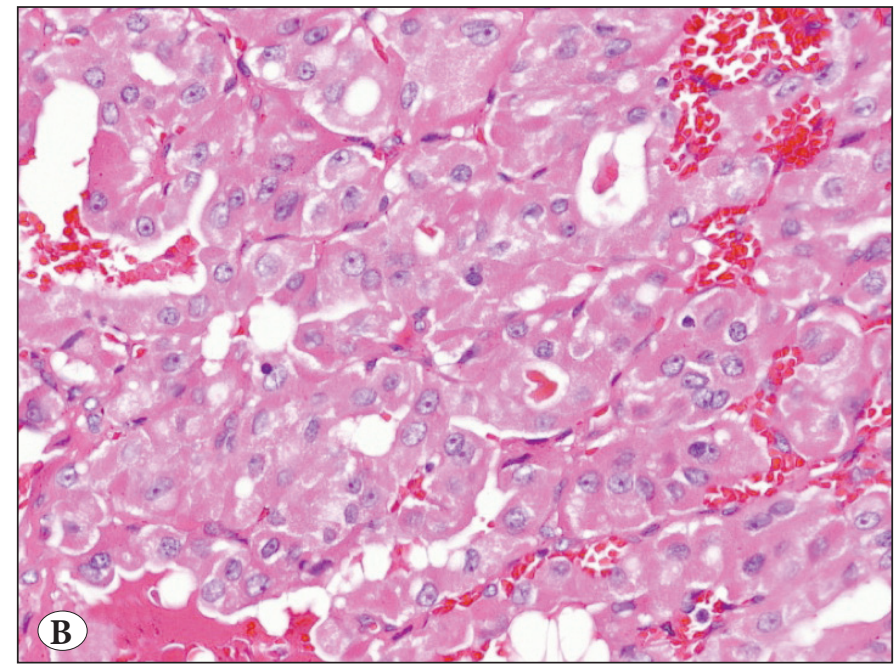

Figure 11: A) An encapsulated tumor consisting of cells with pink wide cytoplasm. B) Tumor nuclei show papillary carcinoma features: oncocytic variant PTC. 
require the use of TTF1, thyroglobulin and other relevant markers (Figure 13A,B)(1,3,4). Behavior is similar to that of classical PTC (66).

\section{DIFFUSE SCLEROSING (SCLEROSIS) VARIANT}

Diffuse sclerosing variant of papillary thyroid carcinoma (DCV-PTC) is a rare neoplasm, accounting for $0.7-6.6 \%$ of all papillary thyroid carcinomas $(1,3,4)$. Patients are frequently reported to be younger than patients with classic papillary carcinoma (67-71). It is reported to be the major subtype of papillary carcinoma (49\%) in patients $<20$ years at diagnosis, in a series of 68 pediatric thyroid carcinomas (72).

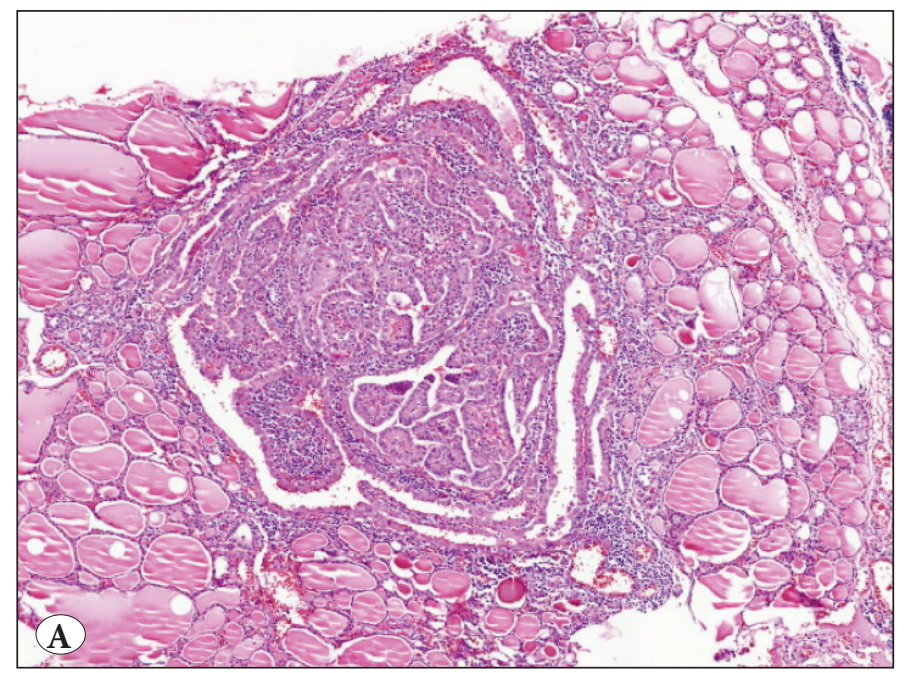

This tumor is characterized by diffuse and extensive involvement of one or both lobes usually without forming a gross tumor nodule. There is extensive sclerosis and lymphoid infiltration in the thyroid with small and dispersed tumor islands many lying within dilated lymphatics. Tumor commonly shows squamous metaplasia and prominent psammoma bodies (Figure 14A,B). When a dominant tumor nodule is present, it usually shows the features of a classical papillary carcinoma or occasionally shows a predominantly follicular organization (1-4,67-71). This variant may be misinterpreted as thyroiditis because of its predominantly diffuse character, presence of chronic lymphocytic thyroiditis in the non tumoral thyroid and serologic evidence of autoimmune thyroid disease (1). It

Figure 12: A) A papillary tumor with lymphoctic infiltration on fibrovascular cores reminiscent of Warthin tumor of salivary glands. B) Higher magnification.
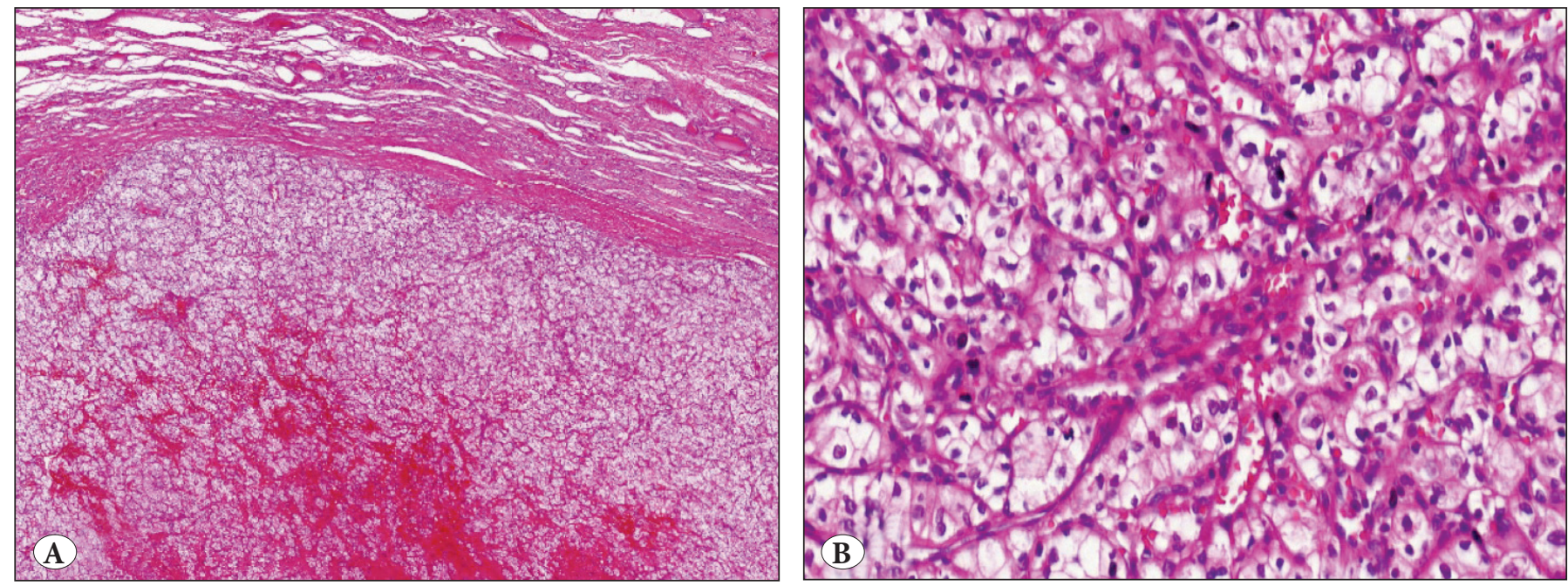

Figure 13: A) A clear cell tumor presenting as a thyroid nodule. B) Higher magnification. This tumor was negative for TTF1 and thyroglobulin. A renal cell carcinoma was found on further clinical examination. 

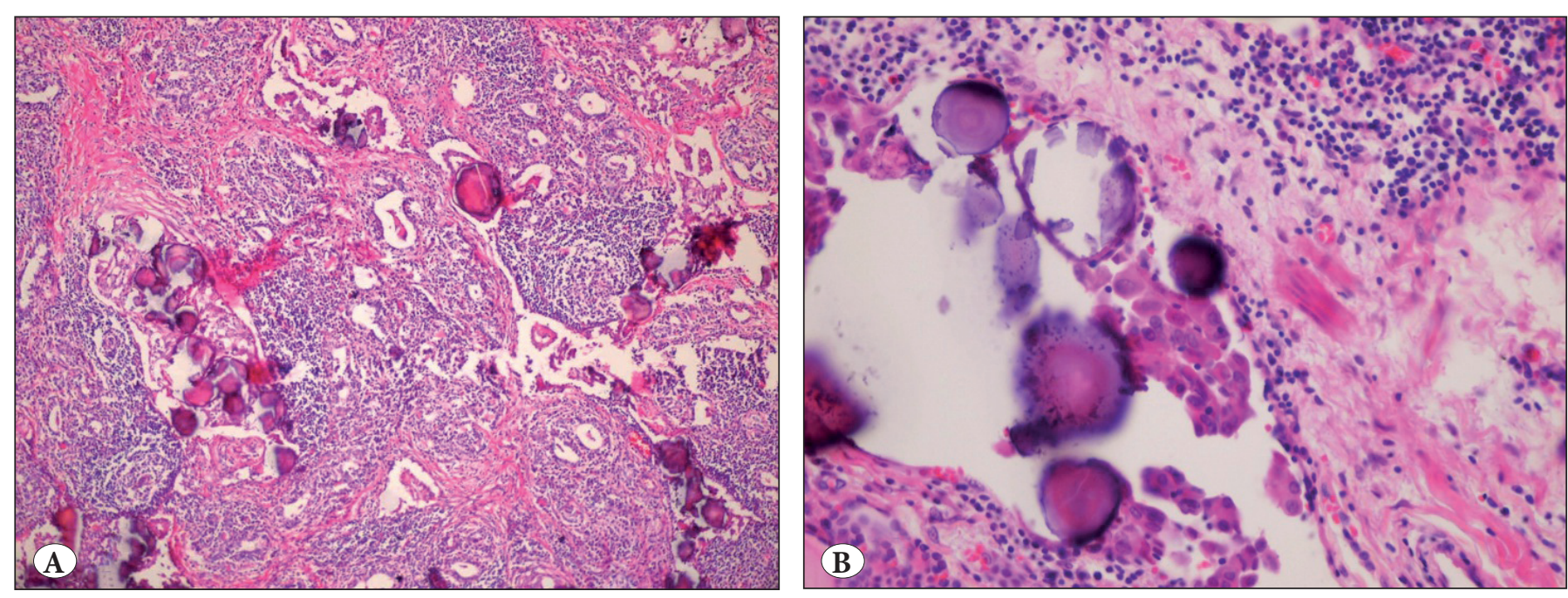

Figure 14: A) Dispersed small tumor groups on lymphocytic thyroiditis background and numerous psammoma bodies. B) Higher magnification shows small tumor cell groups.

may be useful to note that DSV-PTC may show positive staining for estrogen and progesterone receptor (73).

Diffuse sclerosing variant frequently shows RET/PTC rearrangement; whereas $B R A F$ mutation is reported to be rare (74), except for a study from Korea reporting $B R A F$ mutation in $61 \%$ of DSV-PTC cases (75). Recently, ALK gene rearrangement was identified in 13\% of DSV-PTC, as opposed to $2.2 \%$ of unselected PTC cases (76).

Some studies have reported this variant to be more aggressive with prominent regional lymph node and distant (lung) metastases $(69,71)$. On the other hand, the 5- and 10year survival rates of DSV-PTC were found to be $95 \%$ and 93\% respectively in other studies, similar to conventional PTC. In a recent study, 10-year CSS (cause specific survival) and DFS (disease free survival) rates for $<45$ years old DSV patients were found to be 100 and $60.5 \%$ respectively (77). It is likely that different treatment protocols in DSV patients accounted for the variable prognostic outcomes (78). In a recent data analysis, it was reported that approximately $14 \%(n=89 / 641)$ of the patients with DSV-PTC showed recurrence and disease related mortality was noted in 3\% $(n=19 / 641)$ of the total DSV-PTC cases (74).

\section{PAPILLARY CARCINOMA WITH FASCIITIS LIKE STROMA}

This rare variant is characterized by the presence of an abundant nodular fasciitis or fibromatosis like reactive stroma which can mask the neoplastic epithelial component of the tumor in some areas $(1,3,4,79-82)$. To date, less than 30 cases have been reported. The clinical features are similar to those of conventional PTC. The immunohistochemical profile of the spindle cells is consistent with that of myofibroblasts $(79,80)$. Pathologist should be careful not to interpret the lesion on the basis of the stromal component as benign fibrosis, sarcoma or an anaplastic carcinoma. Extensive sampling of the lesion or recuts may be necessary to find the diagnostic papillary carcinoma areas. Benign morphology and non epithelial nature of the spindle cells (cytokeratin negative; vimentin and actin positive) and the presence of typical PTC areas should allow the accurate diagnosis. Presence of BRAF mutation has been reported in this variant (82). The behavior appears to be similar to that of conventional PTC $(1,3)$.

\section{OTHER VARIANTS}

PTC can show some additional morphological features that are sometimes called 'variants' by some authors. PTC may show some non-papillary elements. Some papillary carcinomas may have a minor trabecular or insular component (83). The clinical significance is not certain, but some studies suggest a less favorable outcome (1). Papillary carcinoma (frequently the tall cell variant) rarely coexists with squamous cell carcinoma. This combination shows an aggressive clinical course. It can also be admixed with mucoepidermoid carcinoma. Papillary carcinomas may rarely have a focal undifferentiated component. It is generally accepted that this tumor results from dedifferentiation of the preexisting papillary carcinoma (84). The tumor should be designated as undifferentiated carcinoma in case the spindle or giant cell carcinoma component predominates (1). Mixed medullary-papillary carcinomas are out of the scope of this review. Some stromal changes may be striking enough to be termed as a 'variant' by some observers. 

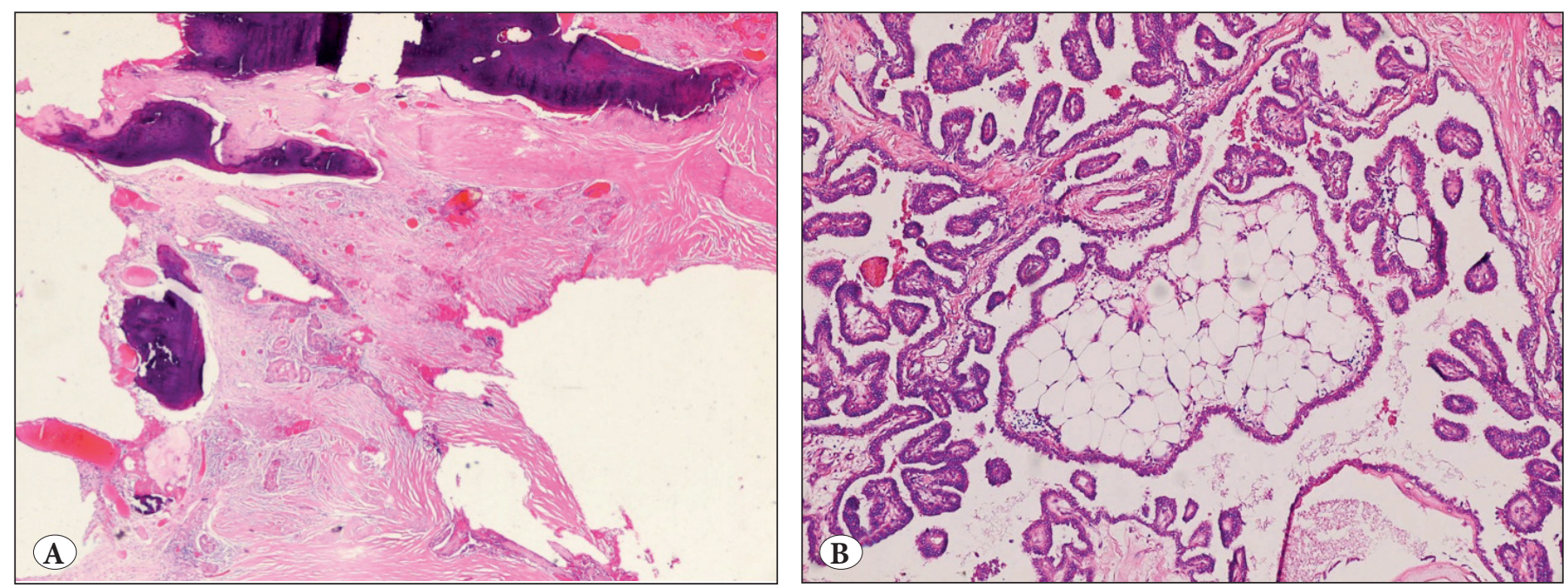

Figure 15:A) Extensive bone formation in PTC. B) Mature fat on fibrovascular stalks of PTC.

Stromal bone formation which is not a rare finding in thyroid tissue, may be very prominent in some PTC cases (Figure 15A) (85). Extensive sampling may be necessary for some cases to find PTC within a bone hard nodule. Papillary carcinomas may also contain some amount of mature adipose tissue in their stroma (Figure 15B) $(86,87)$.

\section{CONCLUSION}

It is important to know all the possible morphological demonstrations of PTC to recognize this common tumor of the thyroid. Although some variants are just morphological challenges for the pathologists, some others may behave worse than conventional PTC and need a more aggressive clinical management. Unencapsulated FV-PTC and diffuse (multinodular) follicular variant may have distant metastases like follicular carcinoma and the patients should be followed accordingly. Diagnosis of CMV-PTC should prompt examination of gastrointestinal system for its association with FAP. It should be noted that, it is not rare to find a PTC showing characteristics of more than one variant. For example: an individual tumor can show hobnail features and present as a microcarcinoma; another case can show solid architecture and clear cytoplasm. In such cases, it is more important to comment on clinically relevant morphological characteristics of the tumor, rather than religiously trying to classify an individual tumor into a particular category.

\section{CONFLICT OF INTEREST}

The author has declared no conflict of interest.

\section{REFERENCES}

1. Livolsi VA, Albores-Saavedra J, Asa SL, Baloch ZW, SobrinhoSimoes M, Wenig B, DeLellis RA, Cady B, Mazafferi EL, Hay I, Fagin JA, Weber AL, Caruso P, Voutilainen PE, Franssila KO, Williams ED, Schneider AB, Nikiforov Y, Rabes HN, Akslen L, Ezzat S, Santoro M, Eng C, Harach HR. Papillary carcinoma. In: DeLellis RA, Lloyd RV, Heitz PU, Eng C editors. WHO classification of tumours, pathology \& genetics: Tumours of endocrine organs. Lyon: IARC Press; 2004. 57-66.

2. Rosai J, Tallini G. Thyroid gland. In: Rosai J editor. Rosai and Ackerman's surgical pathology. $10^{\text {th }}$ ed. New York: Mosby Elsevier 2011:487-564.

3. Nikiforov YE, Ohori NP. Papillary carcinoma. In: Nikiforov YE, Biddinger PW, Thompson LDR editors. Diagnostic pathology and molecular genetics of the thyroid: A comprehensive guide for practicing thyroid pathology. $2^{\text {nd }}$ edition. Philadelphia: Wolter Kluver /Lippincott Williams \&Wilkins; 2012. 183-246.

4. Boerner SL, Asa SL. Biopsy interpretation series: Biopsy interpretation of the thyroid. Epstein JI, editor. Philadelphia: Wolter Kluver /Lippincott Williams \&Wilkins; 2009.

5. Kovács GL, Gonda G, Vadász G, Ludmány E, Uhrin K, Görömbey Z, Kovács L, Hubina E, Bodó M, Góth MI, Szabolcs I. Epidemiology of thyroid microcarcinoma found in autopsy series conducted in areas of different iodine intake. Thyroid. 2005;15(2):152-7.

6. Piersanti M, Ezzat S, Asa SL. Controversies in papillary microcarcinoma of the thyroid. Endocr Pathol. 2003;14(3):18391.

7. Roti E, degli Uberti EC, Bondanelli M, Braverman LE. Thyroid papillary microcarcinoma: a descriptive and meta-analysis study. Eur J Endocrinol. 2008;159(6):659-73.

8. Li F, Chen G, Sheng C, Gusdon AM, Huang Y, Lv Z, Xu H, Xing M, Qu S.BRAFV600E mutation in papillary thyroid microcarcinoma: a meta-analysis. Endocr Relat Cancer. 2015;22(2):159-68. 
9. Rosai J, LiVolsi VA, Sobrinho-Simoes M, Williams ED. Renaming papillary microcarcinoma of the thyroid gland: the Porto proposal. Int J Surg Pathol. 2003;11(4):249-51.

10. Suster S. Thyroid tumors with a follicular growth pattern, problems in differential diagnosis. Arch Pathol Lab Med. 2006;130:984-8.

11. Baloch ZW, Livolsi VA. Encapsulated follicular variant of papillary thyroid carcinoma. Mod Pathol. 2000;13(8):861-5.

12. Liu J, Singh B, Tallini G, Carlson DL, Katabi N, Shaha A, Tuttle RM, Ghossein RA. Follicular variant of papillary thyroid carcinoma. A clinicopathologic study of a problematic entity. Cancer. 2006;107(6):1256-64.

13. Baloch ZW, LiVolsi VA. Follicular-patterned afflictions of the thyroid gland: reappraisal of the most discussed entity in endocrine pathology. Endocr Pathol. 2014; 25:12-20.

14. Mete O, SL Asa. Pitfalls in the diagnosis of follicular epithelial proliferations of the thyroid. Adv Anat Pathol. 2012;19:363-73.

15. Lloyd RV, Ericson LA, Casey MB, Lam KY, Lohse CM, Asa SL, Chan JK, DeLellis RA, Harach HR, Kakudo K, LiVolsi VA, Rosai J, Sebo TJ, Sobrinho-Simoes M, Wenig BM, Lae ME. Observer variation in the diagnosis of follicular variant of papillary thyroid carcinoma. Am J Surg Pathol. 2004;28(11):1336-40.

16. Elsheikh TM, Asa SL, Chan JK, DeLellis RA, Heffess CS, LiVolsi $\mathrm{VA}$, Wenig BM. Interobserver and intraobserver variation among experts in the diagnosis of thyroid follicular lesions with borderline nuclear features of papillary carcinoma. Am J Clin Pathol. 2008;130(5):736-44.

17. Asa SL. The role of immunohistochemical markers in the diagnosis of follicular-patterned lesions of the thyroid. Endocr Pathol. 2005;16:295-309.

18. Fischer S, Asa SL. Application of immunohistochemistry to thyroid neoplasms. Arch Pathol Lab Med. 2008;132:359-72.

19. Cheung CC, Ezzat S, Freeman JL, Rosen IB, Asa SL. Immunohistochemical diagnosis of papillary thyroid carcinoma. Mod Pathol. 2001;14:338-342.

20. Cvejic D, Savin S, Paunovic Tatic S, Havelka M, Sinadinovic J. Immunohistochemical localization of galectin-3 in malignant and benign human thyroid tissue. Anticancer. 1998;18:26372641.

21. Orlandi F, Saggiorato E, Pivano G, Puligheddu B, Termine A, Cappia S, De Giuli P, Angeli A. Galectin-3 is a presurgical marker of human thyroid carcinoma. Cancer Res. 1998;58:3015-3020.

22. Cheng S, Serra S, Mercado M, Ezzat S, Asa SL. A high-throughput proteomic approach provides distinct signatures for thyroid cancer behavior. Clin Cancer Res. 2011;17(8):2385-94.

23. Armstrong MJ, Yang H, Yip L, Ohori NP, McCoy KL, Stang MT, Hodak SP, Nikiforova MN, Carty SE, Nikiforov YE. PAX8/PPARc rearrangement in thyroid nodules predicts follicular-pattern carcinomas, in particular the encapsulated follicular variant of papillary carcinoma. Thyroid. 2014;24:1369-74.

24. Ganly I, Wang L, Tuttle RM, Katabi N, Ceballos GA, Harach $\mathrm{HR}$, Ghossein R. Invasion rather than nuclear features correlates with outcome in encapsulated follicular tumors: further evidence for the reclassification of the encapsulated papillary thyroid carcinoma follicular variant. Hum Pathol. 2015;46:657-64.
25. Vivero M, Kraft S, Barletta JA. Risk stratification of follicular variant of papillary thyroid carcinoma Thyroid. 2013; 23: 273-9.

26. Rosario PW, Penna GC, Calsolari MR. Noninvasive encapsulated follicular variant of papillary thyroid carcinoma: is lobectomy sufficient for tumours $\geq 1 \mathrm{~cm}$ ? Clinical Endocrinology. 2014;81, 629-32.

27. Baloch ZW, LiVolsi VA. Encapsulated follicular variant of papillary thyroid carcinoma with bone metastases. Mod Pathol 2000;13:861-5.

28. Williams ED. Guest Editorial: Two proposals regarding the terminology of thyroid tumors. Int J Surg Pathol. 2000;8(3):1813.

29. Albores-Saavedra J, Gould E, Vardaman C. The macrofollicular variant of papillary carcinoma. A study of 17 cases. Hum Pathol.1991;22:1195-205.

30. Lugli A, Terracciano LM, Oberholzer M Bubendorf L, Tornillo L.Macrofollicular variant of papillary carcinoma of the thyroid: A histologic, cytologic and immunohistochemical study of 3 cases and review of the literature. Arch Pathol Lab Med. 2004;128:548.

31. Ivanova R, Soares P, Castro P, Sobrinho-Simões M. Diffuse (or multinodular) follicular variant of papillary thyroid carcinoma: a clinicopathologic and immunohistochemical analysis of ten cases of an aggressive form of differentiated thyroid carcinoma. Virchows Arch. 2002;440: 418-24.

32. Nikiforov YE. Radiation-induced thyroid cancer: what we have learned from Chernobyl. Endocr Pathol. 2006;17(4):307-17.

33. Harach HR, Williams GT, Williams ED. Familial adenomatous polyposis associated thyroid carcinoma: a distinct type of follicular cell neoplasm. Histopathology. 1994;25(6):549-61.

34. Baloch ZW, Segal JP, Livolsi VA. Unique growth pattern in papillary carcinoma of the thyroid gland mimicking adenoid cystic carcinoma. Endocr Pathol. 2011;22(4):200-5.

35. Asioli S, Maletta F, Pagni F, Pacchioni D, Vanzati A, Mariani S, Palestini N, Lloyd RV, Sapino A. Cytomorphologic and molecular features of hobnail variant of papillary thyroid carcinoma: case series and literature review. Diagn Cytopathol. 2014;42(1):78-84.

36.Asioli S, Erickson LA, Sebo TJ, Zhang J, Jin L, Thompson GB, Lloyd RV. Papillary thyroid carcinoma with prominent hobnail features: A new aggressive variant of moderately differentiated papillary carcinoma. A clinicopathologic, immunohistochemical, and molecular study of eight cases. Am J Surg Pathol. 2010;34:4452.

37.Asioli S, Erickson LA, Righi A, Lloyd RV. Papillary thyroid carcinoma with hobnail features: Histopathologic criteria to predict aggressive behavior. Hum Pathol. 2013;44:320-8.

38. Lino-Silva LS, Domínguez-Malagón HR, Caro-Sánchez $\mathrm{CH}$, Salcedo-Hernández RA. Thyroid gland papillary carcinomas with "micropapillary pattern," a recently recognized poor prognostic finding: clinicopathologic and survival analysis of 7 cases. Hum Pathol. 2012;43:1596-1600.

39. Lubitz CC, Economopoulos KP, Pawlak AC, Lynch K, DiasSantagata D, Faquin WC, Sadow PM. Hobnail variant of papillary thyroid carcinoma: an institutional case series and molecular profile. Thyroid. 2014;24(6):958-65. 
40. Motosugi U, Murata S, Nagata K, Yasuda M, Shimizu M. Thyroid papillary carcinoma with micropapillary and hobnail growth pattern: a histological variant with intermediate malignancy? Thyroid. 2009;19(5):535-7.

41. Johnson TL,Lloyd RV, Thompson NW, Beieralts WH, Sisson J. Prognostic Implictions of the tall cell variant of papillary carcinoma. Am J SurgPathol.1988;12(1): 22-7.

42. Machens A, Holzhausen HJ, Lautenschläger C, Dralle H.The tallcell variant of papillary thyroid carcinoma: a multivariate analysis of clinical risk factors. Langenbecks Arch Surg. 2004; 389:278-82.

43. Michels JJ, Jacques M,Henry-Amar M,Bardet S.Prevalence and prognostic significance of tall cell variant of papillary thyroid carcinoma. Hum Pathol.2007;38(2):212-9.

44. Axelsson TA, Hrafnkelsson J, Olafsdottir EJ, Jonasson JG. Tall cell variant of papillary thyroid carcinoma: A population-based study in Iceland. Thyroid. 2015;25:216-220.

45. Boutzios G,Vasileiadis I,Zapanti E,Charitoudis G,Karakostas E,Ieromonachou P,Karatzas T. Higher incidence of tall cell variant of papillary thyroid carcinoma in Graves' Disease. Thyroid. 2014;24:347-354.

46. Ostrowski ML, Merino MJ. Tall cell variant of papillary carcinoma: A reassessment and immunohistochemical study with comparison to the usual type of papillary carcinoma of the thyroid. Am J SurgPathol. 1996;20(8):964-974.

47. Ghossein RA, Leboeuf R, Patel KN, Rivera M, Katabi N, Carlson DL, Tallini G, Shaha A, Singh B, Tuttle RM. Tall cell variant of papillary thyroid carcinoma without extrathyroid extension: biologic behavior and clinical implications. Thyroid. 2007;17(7):655-61.

48. Tahmasebi FC, Farmer P, Powell SZ, Aldape KD, Fuller GN, Patel S, Hollis P, Chalif D, Eisenberg MB, Li JY. Brain metastases from papillary thyroid carcinomas. Virchows Arch; 2013: 462:473-480.

49. Evans HL. Columnar cell carcinoma of the thyroid: A report of two cases of an aggressive variant of thyroid carcinoma. Am J ClinPathol.1986; 85:77-80.

50. Ferrerrio JA, Hay ID, Lloyd RV. Columnar cell carcinoma of the thyroid: Report of three additional cases. Hum Pathol.1996;27: 1156-60.

51. Mizukami Y, Nonomura A, Michigishi T, Noguchi M, Nakamura S, Hashimoto T. Columnar-cell carcinoma of the thyroid gland a case report and review of the literature. Hum Pathol. 1994;25:1098-101.

52. Sobrinho-Simões M, Nesland JM, Johannessen JV. Columnar-cell carcinoma. Another variant of poorly differentiated carcinoma of the thyroid. Am J ClinPathol. 1988;89:264-7.

53. Wenig BM, Thompson LDR, Adair CF, Shmookler B, Heffess CS. Thyroid papillary carcinoma of columnar cell type: A clinicopathologic study of 16 cases. Cancer 1997;82:740-53.

54. Sujoy V, Pinto A, Nosé V. Columnar Cell Variant of Papillary Thyroid Carcinoma: A Study of 10 Cases with Emphasis on CDX2 Expression. Thyroid. 2013;23:714-7.

55. Enriquez ML, Baloch ZW, Montone KT, Zhang PJ, LiVolsi VA. CDX2 Expression in Columnar Cell Variant of Papillary Thyroid Carcinoma. Am J ClinPathol.2012;137:722-6.
56. Chen JH, Faquin WC, Lloyd RV, NoséV. Clinicopathological and molecular characterization of nine cases of columnar cell variant of papillary thyroid carcinoma. Modern Pathology. 2011;24:73949.

57. Berho M, Suster S. The oncocytic variant of papillary carcinoma of the thyroid: A clinicopathologic study of 15 cases. Hum Pathol .1997;28:47-53.

58. Baloch ZW, Livolsi VA. Oncocytic lesions of the neuroendocrine system. Sem Diagn Path. 1999;16(2):90-9.

59. Sobrinho-Simões M, Preto A, Rocha AS, Castro P, Máximo V, Fonseca E, Soares P Molecular pathology of well-differentiated thyroid carcinomas. Virchows Arch. 2005;447(5):787-93.

60. Trovisco V, Soares P, Preto A, de Castro IV, Lima J, Castro P, Máximo V, Botelho T, Moreira S, Meireles AM, Magalhães J, Abrosimov A, Cameselle-Teijeiro J, Sobrinho-Simões M. Type and prevalence of BRAF mutations are closely associated with papillary thyroid carcinoma histotype and patients' age but not with tumour aggressiveness. Virchows Arch. 2005;446(6):589-95.

61. Cheung CC, Ezzat S, Ramyar L, Freeman JL, Asa SL. Molecular basis of Hurthle cell papillary thyroid carcinoma. J Clin Endocrinol Metab. 2000 Feb;85(2):878-82.

62. Paliogiannis P, Attene F, Trogu F, Trignano M. Warthin-like papillary carcinoma of the thyroid gland: case report and review of the literature. Case Rep Oncol Med. 2012; Article ID 689291.

63. Erşen A, Durak MG, Canda T, Sevınç AI, Saydam S, Koçdor MA.Warthin-like papillary carcinoma of the thyroid: a case series and review of the literature. Turk Patoloji Derg. 2013;29(2):150-5.

64. Amico P1, Lanzafame S, Li Destri G, Greco P, Caltabiano R, Vecchio GM, Magro G. Warthin tumor-like papillary thyroid carcinoma with a minor dedifferentiated component: report of a case with clinicopathologic considerations. Case Rep Med. 2010;2010:495281.

65. Lam KY, Lo CY, Wei WI. Warthin tumor-like variant of papillary thyroid carcinoma: a case with dedifferentiation (anaplastic changes) and aggressive biological behavior. Endocr Pathol. 2005;16(1):83-9.

66. Schröder S, Böcker W. Clear-cell carcinomas of thyroid gland: a clinicopathological study of 13 cases. Histopathology. 1986;10(1):75-89.

67. Fujimoto Y, Obara T, Ito Y, Kodama T, Aiba M, Yamaguchi K.Diffuse sclerosing variant of papillary carcinoma of the thyroid clinical importance, surgical treatment and follow up study. Cancer. 1990; 66:2306-12.

68. Lam AKY, Lu CY. Diffuse sclerosing variant of papillary carcinoma of the thyroid: A 35 year comparative study at a single institution. Ann Surg Oncol . 2006;13(2):176-81.

69. Carcangiu ML, Bianchi S. Diffuse Sclerosing variant of papillary thyroid carcinoma. Clinicopathologic study of 15 cases. Am J SurgPathol.1989;13(12):1041-49.

70. Chow SM, Chan JK, Law SC, Tang DL, Ho CM, Cheung WY, Wong IS, Lau WH. Diffuse sclerosing variant of papillary thyroid carcinoma-clinical features and outcome. Eur J Surg Oncol. 2003;29:446-9.

71. Soares J, Limbert E, Sobrinho-Simões M. Diffuse sclerosing variant of papillary thyroid carcinoma: A clinicopathologic study 
of 10 cases. Path Res Pract. 1989. 185:200-6.

72. Koo JS, Hong S, Park CS. Diffuse sclerosing variant is a major subtype of papillary thyroid carcinoma in the young thyroid. 2009;19:1225-31.

73. Kinoshita Y, Takasu K, Yuri T, Yoshizawa K, Emoto Y, Tsubura A, Shikata N. Estrogen Receptor and Progesterone Receptor Positive Diffuse Sclerosing Variant of Papillary Thyroid Carcinoma: A Case Report. Case Rep Oncol. 2013;6:216-23.

74. Pillai S, Gopalan V, Smith RA, AKY Lam. Diffuse sclerosing variant of papillary thyroid carcinoma-an update of its clinicopathological features and molecular biology. Cri Rev Oncol Hematol. 2015;94:64-73.

75. Lim JY, Hong SW, Lee YS, Kim BW, Park CS, Chang HS, Cho JY. Clinicopathologic implications of the BRAF (V600E) mutation in papillary thyroid cancer: a subgroup analysis of 3130 cases in a single center. Thyroid 2013;23:1423-30.

76. Chou A, Fraser S, Toon CW, Clarkson A, Sioson L, Farzin M, Cussigh C, Aniss A, O'Neill C, Watson N, Clifton-Bligh RJ, Learoyd DL, Robinson BG, Selinger CI, Delbridge LW, MD, Sidhu SB, O'Toole SA, Sywak M, Gill AJ. A Detailed clinicopathologic study of ALK-translocated papillary thyroid carcinoma. Am J Surg Pathol. 2015;39:652-9.

77. Akaishi J, Sugino K, Kameyama K, Masaki C, Matsuzu K, Suzuki A, Uruno T, Ohkuwa K, Shibuya H, Kitagawa W, Nagahama $\mathrm{M}$, Shimizu K, Ito K. Clinicopathologic features and outcomes in patients with diffuse sclerosing variant of papillary thyroid carcinoma. World J Surg. 2015;39(7):1728-35.

78. Regalbuto C, Malandrino P, Tumminia A, Le Moli AR,Vigneri R,Pezzino V. A Diffuse Sclerosing Variant of Papillary Thyroid Carcinoma: Clinical and Pathologic Features and Outcomes of 34 Consecutive Cases. Thyroid. 2011;21:383-9.
79. Chan JKC, Carcangiu ML, Rosai J. Papillary carcinoma of thyroid with exuberant nodular fasciitis-like stroma. Report of three cases. Am J Clin Path . 1990;95:309-14.

80. Terayama K, Toda S, Yonemitsu N. Papillary carcinoma of the thyroid with exuberant nodular fasciitis-like stroma. Virchows Arch.1997;431:291-5.

81. Na KY, Kim HS, Sung JY, Park WS, Kim YW. Papillary carcinoma of the thyroid gland with nodular fasciitis-like stroma. Korean J Pathol. 2013; 47: 167-171.

82. Ginter PS, Scognamiglio T. Papillary thyroid carcinoma with nodular fasciitis-like stroma: a usual entity with distinctive morphology. Int J SurgPathol. 2015;23(4):305-7

83. Rufini VI, Salvatori M, Fadda G, Pinnarelli L, Castaldi P, Maussier ML, Galli G. Thyroid carcinomas with a variable insular component: prognostic significance of histopathologic patterns. Cancer. 2007;15:1209-17.See comment in PubMed Commons below

84. Albores-Saavedra J, Hernandez M, Sanches-Sosa S. Histologic variants of papillary and follicular carcinomas associated with anaplastic spindle and giant cell carcinomas of the thyroid : An analysis of rhabdoid and thyroglobulin inclusions. Am J Surg Pathol. 2007;31:729-36.

85. Na KY, Kim HS, Lee SK, Jung WW, Sung JY, Kim YW, Park YK. Papillary thyroid carcinoma with bone formation. Pathol Res Pract. 2013;209(1):14-8.

86. DeRienzo D, Truong L. Thyroid neoplasms containing mature fat: a report of two cases and review of the literature. Mod Pathol. 1989;2(5):506-10.

87. Vestfrid MA. Papillary carcinoma of the thyroid gland with lipomatous stroma: Report of a peculiar histological type of thyroid tumour. Histopathology. 1986;10:97-100. 